\title{
Changes in ichthyofauna composition along a gradient from clearwaters to blackwaters in coastal streams of Atlantic forest (southeastern Brazil) in relation to environmental variables
}

\author{
Cristina da Silva Gonçalves and Francisco Manoel de Souza Braga
}

The lack of knowledge of the freshwater ichthyofauna of coastal streams in the State of São Paulo (Brazil) is a cause of concern, as these streams are inserted in the Atlantic forest, a hotspot highly threatened. The aim of the present study is to investigate the freshwater ichthyofauna composition of clear and blackwater streams in a preservation area of Brazilian Atlantic forest. Fish samples were taken using electrofishing. A total of 20 species were registered, with Astyanax ribeirae, Hollandichthys multifasciatus, and Mimagoniates microlepis (Characiformes, Characidae) as the more representative. In general, the observed pattern of occurrence and distribution of fish species varied according to habitat characteristics, due to the longitudinal gradient in clearwaters, and among clearwaters and blackwaters. In clearwater streams, the headwater stretches had lower species diversity, while the opposite occurred in the middle and lower sites. These longitudinal variations of ichthyofauna were related with habitat characteristics (depth, stream flow, and bottom type) in which they were found, since the diversity of habitats was higher in headwaters and lower in downstream reaches (middle and lower sites). The physical and chemical variables of water do not seem to have influenced the distribution of species in clearwater streams, but the clear and blackwater fish composition was influenced mainly by $\mathrm{pH}$ concentration. Unlike the spatial differences, significant temporal differences were not registered in fish assemblages, probably due to the absence of a pronounced dry season in the studied region.

A falta de conhecimento dos peixes de água doce em riachos costeiros no estado de São Paulo é preocupante, considerando que estes riachos estão inseridos em um bioma brasileiro extremamente ameaçado, a floresta Atlântica. O objetivo deste trabalho é investigar a composição da ictiofauna de riachos de águas claras e pretas em uma área preservada da Mata Atlântica. A pesca elétrica foi utilizada para amostrar a ictiofauna. Foram coletadas 20 espécies, sendo Astyanax ribeirae, Mimagoniates microlepis e Hollandichthys multifasciatus (Characiformes, Characidae), as mais representativas. De modo geral, o padrão de ocorrência e distribuição da ictiofauna observado variou de acordo com as características dos habitats, tanto no gradiente longitudinal nos riachos de águas claras, quanto entre os riachos de águas claras e o de águas pretas. Nos riachos de águas claras, os trechos de cabeceiras apresentaram riqueza e diversidade de espécies menor, enquanto o inverso ocorreu nos pontos médios e inferiores. Estas variações longitudinais da ictiofauna provavelmente estão associadas às características dos ambientes (profundidade, correnteza e substrato) em que foram encontradas, visto que a diversidade de habitats foi maior nos trechos de cabeceiras e menor nos trechos médios e inferiores. As variáveis físicas e químicas da água parecem não ter influenciado tanto a distribuição das espécies nos riachos de águas claras, porém as diferenças na composição da ictiofauna entre riachos de águas claras e de águas pretas foram influenciadas principalmente pelo $\mathrm{pH}$. Ao contrário das diferenças espaciais, não foram registradas diferenças temporais nas ictiocenoses, provavelmente devido à ausência de um período seco pronunciado na região de estudo.

Key words: Fish structure, Habitat diversity, Jureia-Itatins, pH concentration.

\section{Introduction}

One of the challenges for stream fish ecologists until today is to understand the mechanisms and processes responsible for fish structuring (Gido \& Jackson, 2010). The structure of fish assemblages in streams can be influenced by factors that act on the temporal and spatial dimensions. In the first case, fish abundance and distribution are influenced by the combination of historical, evolutionary and biogeographical processes, including contemporaneous aspects (daily, seasonally, and yearly variations), while the spatial dimension considers global, regional and local scales (Matthews, 1998; Winemiller et al., 2008).

Universidade Estadual Paulista "Júlio de Mesquita Filho" (UNESP), Instituto de Biociências, Departamento de Zoologia. Av. 24-A, 1515, 13.506-900 Rio Claro, SP, Brazil.cristina.silva.goncalves@gmail.com 
Several studies conducted both in temperate (e.g. Sheldon, 1968; Horwitz, 1978; Angermeier \& Schlosser, 1989) and tropical (e.g. Angermeier \& Karr, 1983; Angermeier \& Schlosser, 1989; Gilliam et al., 1993) environments, have shown that ichthyofauna diversity increases from upstream to downstream areas and that there is a positive relationship between fish diversity and habitat diversity (Gorman \& Karr, 1978; Ibañez et al., 2009). In Brazil, such patterns were also found for several inland streams (e.g., Braga \& Andrade, 2005; Casatti, 2005). In coastal drainages, the influence of the longitudinal gradient in the structure of fish assemblages of clearwater streams was investigated from the production rate (Mazzoni \& Lobón-Cerviá, 2000), habitat (Mazzoni \& Iglesias-Rios, 2002; Gerhard et al., 2004; Barreto \& Aranha, 2005; Guimarães et al., 2010), species composition (Uieda \& Uieda, 2001; Ferreira \& Petrere Jr., 2009), and trophic (Esteves \& Lobón-Cerviá, 2001) perspectives, among others. Blackwater streams occur in temperate and tropical forests (Meyer, 1990), and in Brazil, the hydrochemical differences of blackwaters from clearwaters were highlighted in Amazon rivers (Por \& Lopes, 1994), but not in Atlantic forest streams. Little attention was given to the relationship between habitat versus fish diversity in freshwater coastal streams, considering the water variables differences between streams of clear and blackwaters.

The lack of knowledge of the ichthyofauna in coastal streams in the State of São Paulo is a cause of concern (Menezes et al., 2007), as they are inserted in the Atlantic forest, a highly threatened hotspot due to deforestation (Myers et al., 2000; Ribeiro et al., 2009). The popular or technical literature often neglects the conservation of aquatic environments (Menezes et al., 2007), despite the high endemism and diversity of fish in streams in this threatened Brazilian biome (Bizerril, 1994, 1995; Ribeiro, 2006; Menezes et al., 2007; Abilhoa et al., 2011; Oyakawa \& Menezes, 2011). Several species have been described, however, few ecological studies have been conducted so far (e.g., Buck \& Sazima, 1995; Esteves \& Lobón-Cerviá, 2001; Deus \& Petrere Jr., 2003; Gerhard et al., 2004; Ribeiro et al., 2006; Serra et al., 2007; Ferreira \& Petrere Jr., 2009; Mattox \& Iglesias, 2010).

The Jureia-Itatins Ecological Station (JIES) is one of the few protected areas in the State of São Paulo which harbor a significant portion of this biome, but unfortunately, knowledge about ichthyofauna diversity is incipient (e.g., Sabino \& Silva, 2004; Oyakawa et al., 2006). The aim of the present study is to investigate the freshwater ichthyofauna composition of clear and blackwater streams in JIES. Thus, we addressed the following specific questions: (1) Does the fish fauna of clearwater streams differ in relation to the blackwater stream? (2) What is the relationship between habitat diversity and ichthyofauna diversity in clearwater streams? (3) Does the fish fauna of clearwater streams and the blackwater stream vary over 1-year period? We hypothesized that habitat characteristics will reflect the spatial distribution and the diversity of fish species in clear and blackwater streams. Considering the absence of a pronounced dry season in the studied region, temporal variations in ichthyofauna composition are not expected.

\section{Material and Methods}

\section{Study area}

The Juréia-Itatins Ecological Station (JIES) is a conservation area $(80.000 \mathrm{ha})$ located on the south coast in the State of São Paulo, between $24^{\circ} 18^{\prime}-24^{\circ} 32^{\prime}$ S and $47^{\circ} 00^{\prime}-$ $47^{\circ} 30^{\prime} \mathrm{W}$. The climate is classified as humid subtropical without a dry season. The hotter and rainier season occurs from October to April, and a less pronounced rainy season occurs from May to September. The average annual rainfall and temperature are $2,277 \mathrm{~mm}$ and $21.4^{\circ} \mathrm{C}$, respectively. JIES is formed by rocks of the Precambrian Coastal Complex which are predominant and occur in part of the coastal mountains of the Itatins mountain range and in the coastal plains in the State of São Paulo south coast. Several elevations occur along the long stretch of the coastal plain of the eastern lowlands of Ribeira de Iguape River, especially in the Jureia mountain range (altitude around $870 \mathrm{~m}$ ). Although the Atlantic rainforest covers many vegetation types, the dense ombrophilous forest and "restinga" forest are predominant in mountain and lowland regions, respectively, of the studied area. Rupestrian fields are present at the top of the hills, and mangroves are found along large river estuaries (Marques \& Duleba, 2004). "Restinga" is the usual name that classifies the vegetation of the Brazilian coastal plains formed by sediments of marine origin (Sampaio et al., 2005).

The JIES has a diverse river system including different types of water, classified according to hydrological and chemical characteristics as: mountain streams (clearwaters), lowland or "restinga" streams (blackwaters), and small estuarine areas (transition zones between the marine and freshwater environments) (Por, 1986; Por \& Lopes, 1994). The differences are primarily related to topography, soil type and the vegetation type predominant in the drainage system. Thus, mountain streams that drain the dense ombrophilous forest (Precambrian soils) have clear but nutrient-poor waters $(\mathrm{pH} \sim 5)$, while the lowland streams have blackwaters rich in humic substances ( $\mathrm{pH} \sim 4)$, due to the presence of "restinga" forest (alluvial, podzolic, and hydromorphic soils). The estuarine regions are influenced by the tidal rhythm fluctuations and therefore have brackish waters (Por, 1986; Por \& Lopes, 1994). The JIES area is drained mainly by the middle and lower stretches of Una do Prelado River (or "Comprido" River), a lowland and medium-sized river (100 m), which runs parallel to the sea shore surrounding the Jureia mountain range (Por, 1986; 2004). Additionally, the JIES has a number of smaller streams that drain directly into the sea, as the selected ones in the present study.

\section{Sampling}

Sampled sites included six clearwater streams (ribeirão das Antas, ribeirão Tetequera, ribeirão Grajaúna, "Ponte 2", rio Verde, "Riacho 1"), and one blackwater stream (rio Preto). Quotation marks indicate fictitious names to unnamed streams. The sampled sites were selected to include the upper (site 1), middle (site 2) and lower (site 3) stretches of each stream (except 
rio Preto). The choice of sampled sites was based on topographic maps, considering the structural characteristics of habitat and the altitude of each site. Additional blackwater streams were not selected because they were larger than the other selected streams and/or because of marine influence. Streams near estuaries were avoided because of the strong tidal influence, but despite this, some lower stretches possibly have been affected by brackish waters during high tides. Thus, collections were practiced during low tide whenever possible (periods of waxing and waning moons) to minimize marine influence. Therefore, 19 sampling sites were selected (Table 1). Samplings were made during four occasions (autumn: 08-14 April 2009; winter: 28 July to 04 August 2009; spring: 05-12 November 2009, and summer: 02-09 February 2010).

\section{Environmental variables}

The $\mathrm{pH}$, conductivity, dissolved oxygen and water temperature were measured at each sampling site during the year (four samples). The Winkler method was used to measure the dissolved oxygen, according to Moraes (2001). The other variables were measured in the field using a digital Marte analyzers, models MB 10P and MB 11P.

Habitat structure was evaluated at each site measuring stream width $(\mathrm{m})$, flow $\left(\mathrm{m} . \mathrm{s}^{-1}\right)$, depth $(\mathrm{cm})$, and the predominant bottom type (clay: $<0.05$, sand: $0.05-2$, gravel: $2-10$, pebble: $10-100$, rock: 100-300, boulder: $>300 \mathrm{~mm}$, bed rock, plant debris and silt). A weighted mean was calculated to bottom type, according to the formula: $x=\Sigma\left(f_{i} * x_{i}\right) / \Sigma f_{i}$, considering the numerical frequency $(f)$ and weight $(x)$ of $i$ bottom categories (clay $=1$, sand $=2$, gravel $=$

Table 1. Description of the sampled sites in Jureia-Itatins Ecological Station, indicating the clear $(*)$ and blackwaters $(* *)$ streams, geographic location, channel order (scale 1:50,000), altitude $(\mathrm{m})$, shading and state of preservation of riparian vegetation (P: preserved, PD: partially deforested, D: deforested). Range and average (in parentheses) values of $\mathrm{pH}$, conductivity $\left(\mu \mathrm{S}_{\mathrm{S}} \mathrm{cm}^{-1}\right)$, water temperature $\left({ }^{\circ} \mathrm{C}\right)$, dissolved oxygen $\left(\mathrm{mg} \cdot \mathrm{L}^{-1}\right)$, and Shannon diversity index considering habitat structure $\left(\mathrm{H}^{\prime}\right.$ habitat $)$ at each sampled site, between April 2009 and February 2010. Upper (site 1), middle (site 2) and lower (site 3) stream stretches. Measures of habitat structure were taken during June 2010.

\begin{tabular}{|c|c|c|c|c|c|c|c|c|c|c|c|}
\hline Streams & Sites & Coordinates & Order & Altitude & Shading & $\begin{array}{c}\text { Riparian } \\
\text { vegetation }\end{array}$ & $\mathrm{pH}$ & Conductivity & $\begin{array}{c}\text { Water } \\
\text { temperature }\end{array}$ & $\begin{array}{c}\text { Dissolved } \\
\text { oxygen }\end{array}$ & $\mathrm{H}_{\text {habitat }}$ \\
\hline \multirow{3}{*}{ Antas* } & 1 & $\begin{array}{l}24^{\circ} 21^{\prime} 26.90 ” \mathrm{~S} \\
47^{\circ} 02,15.60 \text { ”'W }\end{array}$ & 2 & 49 & $>76 \%$ & PD & $\begin{array}{c}5.4-6.2 \\
(5.9)\end{array}$ & $\begin{array}{c}44.1-57.5 \\
(50.4)\end{array}$ & $\begin{array}{c}17.5-25.5 \\
(22.2)\end{array}$ & $8.3-10.3(9.3)$ & 2.09 \\
\hline & 2 & $\begin{array}{l}24^{\circ} 21^{\prime} 37.00^{\prime \prime} \mathrm{S} \\
47^{\circ} 02^{\prime} 15.20^{\prime \prime} \mathrm{W}\end{array}$ & 2 & 19 & $>76 \%$ & PD & $\begin{array}{c}5.1-6.1 \\
(5.7)\end{array}$ & $\begin{array}{c}49.9-58.4 \\
(52.8) \\
\end{array}$ & $\begin{array}{c}17.3-25.4 \\
(22.5) \\
\end{array}$ & $8.2-10.4(9.1)$ & 1.93 \\
\hline & 3 & $\begin{array}{c}24^{\circ} 21^{\prime} 43.20^{\prime \prime} \mathrm{S} \\
47^{\circ} 02^{\prime} 15.34^{\prime \prime} \mathrm{W}\end{array}$ & 2 & 15 & $>76 \%$ & PD & $\begin{array}{c}5.2-7.1 \\
(6.0)\end{array}$ & $\begin{array}{c}43.9-57.0 \\
(49.9) \\
\end{array}$ & $\begin{array}{c}17.5-27.5 \\
(23.0) \\
\end{array}$ & $8.0-9.0(8.6)$ & 1.71 \\
\hline \multirow{3}{*}{ Tetequera* } & 1 & $\begin{array}{c}24^{\circ} 23 ' 18.00 " \mathrm{~S} \\
47^{\circ} 05^{\prime} 53.70 ” \mathrm{~W}\end{array}$ & 1 & 41 & $26-50 \%$ & PD & $\begin{array}{c}5.3-5.8 \\
(5.5) \\
\end{array}$ & $\begin{array}{c}26.1-45.2 \\
(39.0)\end{array}$ & $\begin{array}{c}17.0-26.3 \\
(22.3) \\
\end{array}$ & $\begin{array}{c}8.0-14.4 \\
(10.3) \\
\end{array}$ & 2.38 \\
\hline & 2 & 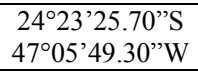 & 2 & 25 & $0-25 \%$ & $\mathrm{D}$ & $\begin{array}{c}4.9-5.6 \\
(5.2)\end{array}$ & $\begin{array}{c}36.9-46.8 \\
(42.9) \\
\end{array}$ & $\begin{array}{c}17.5-25.8 \\
(22.3)\end{array}$ & $\begin{array}{c}7.8-16.8 \\
(11.4) \\
\end{array}$ & 2.21 \\
\hline & 3 & $\begin{array}{c}24^{\circ} 23^{\prime} 00.20^{\prime \prime} \mathrm{S} \\
47^{\circ} 04^{\prime} 50.30^{\prime \prime} \mathrm{W}\end{array}$ & 2 & 16 & $51-75 \%$ & PD & $\begin{array}{c}4.8-6.0 \\
(5.5)\end{array}$ & $\begin{array}{c}40.2-50.7 \\
(45.4) \\
\end{array}$ & $\begin{array}{c}17.5-28.2 \\
(23.9) \\
\end{array}$ & $8.2-9.6(9.3)$ & 2.12 \\
\hline \multirow{3}{*}{ Grajaúna* } & 1 & $\begin{array}{c}24^{\circ} 31^{\prime} 03.10^{\prime \prime} \mathrm{S} \\
47^{\circ} 12^{\prime} 48.90^{\prime \prime} \mathrm{W}\end{array}$ & 1 & 60 & $>76 \%$ & $\mathrm{P}$ & $\begin{array}{c}5.4-6.6 \\
(6.3) \\
\end{array}$ & $\begin{array}{c}44.8-62.3 \\
(55.7) \\
\end{array}$ & $\begin{array}{c}18.0-25.7 \\
(22.4) \\
\end{array}$ & $7.2-10.3(8.5)$ & 2.13 \\
\hline & 2 & $\begin{array}{l}24^{\circ} 31^{\prime} 08.10^{\prime \prime} ! \mathrm{S} \\
47^{\circ} 12^{\prime} 42.90^{\prime \prime} \mathrm{W}\end{array}$ & 2 & 30 & $51-75 \%$ & $\mathrm{P}$ & $\begin{array}{c}4.9-7.1 \\
(6.1) \\
\end{array}$ & $\begin{array}{c}46.0-61.5 \\
(56.9) \\
\end{array}$ & $\begin{array}{c}18.0-24.7 \\
(22.4) \\
\end{array}$ & $7.8-10.1(9.0)$ & 2.12 \\
\hline & 3 & $\begin{array}{c}24^{\circ} 31^{\prime} 17.30^{\prime \prime} \mathrm{S} \\
47^{\circ} 12^{\prime} 04.40^{\prime \prime} \mathrm{W}\end{array}$ & 2 & 15 & $>76 \%$ & $\mathrm{P}$ & $\begin{array}{c}4.6-6.8 \\
(5.7) \\
\end{array}$ & $\begin{array}{c}61.2-67.2 \\
(63.3) \\
\end{array}$ & $\begin{array}{c}18.0-26.5 \\
(22.8)\end{array}$ & $6.8-9.3(7.9)$ & 1.84 \\
\hline \multirow{3}{*}{ "Ponte 2"* } & 1 & $\begin{array}{c}24^{\circ} 32^{\prime} 18.80^{\prime \prime} \mathrm{S} \\
47^{\circ} 12^{\prime} 46.40^{\prime \prime} \mathrm{W}\end{array}$ & 1 & 45 & $>76 \%$ & $\mathrm{P}$ & $\begin{array}{c}5.2-7.9 \\
(6.5)\end{array}$ & $\begin{array}{c}\text { 64.6-87.0 } \\
(74.2) \\
\end{array}$ & $\begin{array}{c}18.2-25.7 \\
(21.8) \\
\end{array}$ & 8.6-9.9 (9.2) & 1.89 \\
\hline & 2 & $\begin{array}{c}24^{\circ} 32^{\prime} 23.00^{\prime \prime} \mathrm{S} \\
47^{\circ} 12^{\prime} 44.90^{\prime \prime} \mathrm{W}\end{array}$ & 2 & 30 & $>76 \%$ & $\mathrm{P}$ & $\begin{array}{c}5.4-7.6 \\
(6.3) \\
\end{array}$ & $\begin{array}{c}59.9-85.4 \\
(71.8) \\
\end{array}$ & $\begin{array}{c}17.9-26.2 \\
(22.1) \\
\end{array}$ & $6.8-10.1(8.0)$ & 1.89 \\
\hline & 3 & $\begin{array}{c}24^{\circ} 32^{\prime} 30.00^{\prime \prime} \mathrm{S} \\
47^{\circ} 12^{\prime} 39.60^{\prime \prime} \mathrm{W}\end{array}$ & 2 & 18 & $>76 \%$ & $P$ & $\begin{array}{c}5.4-8.1 \\
(6.3)\end{array}$ & $\begin{array}{c}62.4-88.0 \\
(71.5) \\
\end{array}$ & $\begin{array}{c}17.9-27.9 \\
(22.8)\end{array}$ & $7.4-13.3(9.5)$ & 1.66 \\
\hline \multirow{3}{*}{ rio Verde* } & 1 & $\begin{array}{c}24^{\circ} 32^{\prime} 52.60^{\prime \prime} \mathrm{S} \\
47^{\circ} 14^{\prime} 37.20^{\prime \prime} \mathrm{W}\end{array}$ & 2 & 90 & $26-50 \%$ & $\mathrm{P}$ & $\begin{array}{c}6.0-7.7 \\
(6.7)\end{array}$ & $\begin{array}{c}39.7-48.4 \\
(43.9)\end{array}$ & $\begin{array}{c}18.0-25.5 \\
(21.8)\end{array}$ & $8.0-10.5(9.2)$ & 2.09 \\
\hline & 2 & $\begin{array}{c}24^{\circ} 32^{\prime} 52.10^{\prime \prime} \mathrm{S} \\
47^{\circ} 14^{\prime} 17.50 \prime \mathrm{W}\end{array}$ & 3 & 60 & $26-50 \%$ & $\mathrm{P}$ & $\begin{array}{c}6.2-7.5 \\
(6.9) \\
\end{array}$ & $\begin{array}{c}44.6-50.5 \\
(47.0) \\
\end{array}$ & $\begin{array}{c}18.9-27.5 \\
(22.9) \\
\end{array}$ & $7.2-10.3(8.9)$ & 2.07 \\
\hline & 3 & $\begin{array}{c}24^{\circ} 32^{\prime} 54.10^{\prime \prime} \mathrm{S} \\
47^{\circ} 14^{\prime} 04.50^{\prime \prime} \mathrm{W}\end{array}$ & 3 & 35 & $26-50 \%$ & $\mathrm{P}$ & $\begin{array}{c}5.5-6.3 \\
(6.0) \\
\end{array}$ & $\begin{array}{c}46.5-51.8 \\
(49.2) \\
\end{array}$ & $\begin{array}{c}17.7-25.5 \\
(21.4) \\
\end{array}$ & $8.0-10.5(9.4)$ & 1.76 \\
\hline \multirow{3}{*}{ "Riacho 1"* } & 1 & $\begin{array}{c}24^{\circ} 33^{\prime} 05.50^{\prime \prime} \mathrm{S} \\
47^{\circ} 13^{\prime} 55.70 " \mathrm{~W}\end{array}$ & 1 & 35 & $>76 \%$ & $\mathrm{P}$ & $\begin{array}{c}5.3-7.2 \\
(6.4)\end{array}$ & $\begin{array}{c}81.3-94.5 \\
(88.3)\end{array}$ & $\begin{array}{c}20.2-22.2 \\
(21.3)\end{array}$ & $\begin{array}{c}7.6-20.5 \\
(11.2) \\
\end{array}$ & 1.72 \\
\hline & 2 & $\begin{array}{c}24^{\circ} 33^{\prime} 02.50^{\prime \prime} \mathrm{S} \\
47^{\circ} 13^{\prime} 55.90^{\prime \prime} \mathrm{W}\end{array}$ & 2 & 21 & $>76 \%$ & $P$ & $\begin{array}{c}5.5-7.3 \\
(6.6) \\
\end{array}$ & $\begin{array}{c}81.1-93.0 \\
(86.8) \\
\end{array}$ & $\begin{array}{c}20.1-24.6 \\
(22.3) \\
\end{array}$ & $8.0-9.0(8.1)$ & 1.78 \\
\hline & 3 & $\begin{array}{c}24^{\circ} 32^{\prime} 59.40 ” \mathrm{~S} \\
47^{\circ} 13^{\prime} 57.90^{\prime \prime} \mathrm{W}\end{array}$ & 2 & 18 & $>76 \%$ & $\mathrm{P}$ & $\begin{array}{c}5.5-8.0 \\
(6.7)\end{array}$ & $\begin{array}{c}86.9-89.2 \\
(88.1)\end{array}$ & $\begin{array}{c}20.0-25.6 \\
(22.5)\end{array}$ & $6.6-8.9(7.3)$ & 1.26 \\
\hline rio Preto** & - & $\begin{array}{c}24^{\circ} 31^{\prime} 17.30^{\prime \prime} \mathrm{S} \\
47^{\circ} 12^{\prime} 04.40^{\prime \prime} \mathrm{W}\end{array}$ & 1 & 14 & $>76 \%$ & $\mathrm{P}$ & $\begin{array}{c}3.2-4.3 \\
(3.9)\end{array}$ & $\begin{array}{c}49.6-80.0 \\
(66.7)\end{array}$ & $\begin{array}{c}17.5-27.3 \\
(23.1)\end{array}$ & $3.3-5.7(4.7)$ & 1.80 \\
\hline
\end{tabular}


3 , pebble $=4$, rock $=5$, boulder $=6$, and bed rock $=7$ ). The shading provided by riparian vegetation cover $(0-25 \%, 26-50 \%, 51-75 \%$ and above $76 \%$ ) and its preservation status (preserved, partially deforested and deforested) were also registered. Habitat structure measures followed Gorman \& Karr (1978), with modifications, i.e, data was obtained in stretches of $100 \mathrm{~m}$, which included the $50 \mathrm{~m}$ stretches where the ichthyofauna was sampled. Ten linear transects were set along stream stretches (one every $10 \mathrm{~m}$ ). Replicate measurements of stream width and flow, channel depth and bottom type were taken every meter along each transect. Stream width and depth were measured with a measuring tape, and stream flow with a mechanical General Oceanics flowmeter. Bottom type was classified visually, considering the established categories. Habitat structure measures were conducted once during 11-20 June 2010 at all sampling sites to provide an environmental characterization of selected streams.

\section{Ichthyofauna}

Fish specimens were caught with electrofishing in stretches of $50 \mathrm{~m}$ in one passage of the equipment (without block seine). Electrofishing gear was used according to the field conditions. In sites easier to access, the electrofisher consisted of a rectifier current (connected to two dip nets) powered by a gasolinedriven Yamaha generator. Sampled sites which were difficult to reach were sampled with a Smith-Root backpack electrofisher (model LR-24, 500V DC), connected to two dip nets. The dip nets were handled by two people who walked slowly upstream in the opposite direction to the stream flow to the upper limit $(50 \mathrm{~m})$. Because of the greater width of the lower point (site 3 ) in rio Verde and in order to make sampling more efficient, this stretch was split in two and sampling performed first in the right bank, and then on the left shore. In April 2009, electrofishing was not performed at the upper stretch (site 1) of the "Riacho 1" due to the low water volume.

Fish specimens were anesthetized with benzocaine, fixed in $10 \%$ formalin for around 48 hours, and then kept in $70 \%$ alcohol until the analysis. Fish specimens were measured to obtain the total and the standard length $(\mathrm{mm})$, and weighted $(\mathrm{g})$.

Identification of fish species was made by specialists, and voucher specimens of freshwater species are deposited in the fish collection of the Coleção de Peixes do Departamento de Zoologia e Botânica do Instituto de Biociências, Letras e Ciências Exatas, Universidade Estadual Paulista, São José do Rio Preto, SP (DZSJRP 13234-13258).

\section{Data analysis}

Environmental variables. The numerical frequencies from categories of structural variables of the habitat, i.e., stream width, depth (shallow: 0-30, moderate: 30-100, deep: $>100 \mathrm{~cm}$ ), flow (very slow: $<0.05$, slow: $0.05-0.2$, moderate: $0.2-0.4$, fast: $0.4-1.0$, very fast: $>1.0 \mathrm{~m} . \mathrm{s}^{-1}$ ), and bottom type (clay: $<0.05$, sand: $0.05-2$, gravel: 2-10, pebble: $10-100$, rock: $100-300$, boulder: $>300 \mathrm{~mm}$, bed rock, plant debris), were used to estimate the habitat diversity of each sampling site $(1,2,3)$ within each stream (Gorman \& Karr, 1978). The Shannon index was calculated to assess habitat diversity $\left(H_{\text {habitat }}^{\prime}\right)$, using the software PAST (Hammer et al., 2001).
A multivariate approach was used to identify the most important factors for fish community structure, considering habitat (width, depth, flow, and bottom type) and water variables $(\mathrm{pH}$, conductivity, dissolved oxygen and temperature) at each sampled site. The dimensionality of data was reduced in the Principal Component Analysis (PCA) and data was $\log (\mathrm{x}+1)$ transformed in order to linearize relationships (Legendre \& Legendre, 1998). Data was treated as continuous both for habitat and water variables, and the mean values were used to water variables. This analysis was performed using the software PAST (Hammer et al., 2001).

Ichthyofauna. The $\alpha$ diversity of ichthyofauna was estimated to each site by the Shannon index $\left(H^{\prime}{ }_{\text {ichthyofauna }}\right)$, considering the six clearwater streams (three sites in each one) and the blackwater stream, during the four temporal collections, using the software PAST (Hammer et al., 2001). In order to verify the differences of $H^{\prime}$ ichthyofauna between sites $(1,2,3)$ and seasons (four temporal collections), we used the following model: $H_{\text {ichthyofauna }}^{\prime}=S_{t}+S_{i}+S_{e}+H_{\text {habitat }}^{\prime}+S_{i} * S_{e}+S_{i} * H_{\text {habitat }}^{\prime}$ $+S_{e} * H^{\prime}$ habitat $+S_{i} * S_{e} * H^{\prime}$ habitat, where $H^{\prime}{ }_{\text {ichthyofauna }}$ is the ichthyofauna diversity estimated by Shannon index, $S_{t}$ is the effect of the streams, $S_{i}$ is the effect of the sites, $S_{e}$ is the effect of the seasons and $H_{\text {habitat }}$ is the habitat diversity estimated by Shannon index. The rio Preto was excluded from this analysis due to the absence of replicate sites in this stream.

A post-hoc test (LSD) was used to verify fish fauna variations among sites $(1,2,3)$ considering the observed species richness and ichthyofauna diversity registered in each clearwaters' stream stretch.

Simple linear regressions were used to verify the dependence of ichthyofauna diversity on habitat diversity to each site $(1,2,3)$, according to the model: $H_{\text {ichthvofauna }}^{\prime}=a+b$ $H_{\text {habitat }}^{\prime}+e$, were $H_{\text {ichthvofauna }}^{\prime}$ is the ichthyofauna diversity estimated by Shannon index, $H^{\prime}$ habitat is the habitat diversity estimated by Shannon index, $e$ is the error (with normal distribution and constant variance), and $a$ and $b$ are the model parameters representing the intercept and the slope, respectively.

To univariate analysis, we considered $\mathrm{p}$-values less than 0.05 statistically significant.

To ordinate the sample sites hierarchically, a cluster analysis was applied to the ichthyofauna abundance matrix, considering the six clearwater streams (three sites in each one) and the blackwater stream. The Bray-Curtis index and the single linkage method were used. Data was $\log (x+1)$ transformed in order to linearize relationships (Legendre \& Legendre, 1998). This analysis was performed using the software PRIMER 6 (Clarke \& Gorley, 2006).

To analyze species-environment relationships, a multivariate approach was used relating the fish species abundance with habitat structural variables (stream width, depth, flow, and bottom type) and the physical and chemical variables of water ( $\mathrm{pH}$, conductivity, dissolved oxygen, and temperature), considering the six clearwater streams (three sites in each one) and the blackwater stream. The 
dimensionality of data was reduced in Canonical Correspondence Analysis (CCA) and data was $\log (\mathrm{x}+1)$ transformed in order to linearize relationships (Legendre \& Legendre, 1998). Data was treated as continuous both for habitat and water variables, and the mean values were used to water variables. This analysis was performed using the software R, version 2.15.1 (R Development Core Team, 2012).

\section{Results}

\section{Environmental variables}

The characteristics of the sampled sites, such as the preservation status of riparian vegetation and the shading that it provides to streams are presented in Table 1.

Overall, data of physical and chemical water variables were similar among clearwater streams (Table 1). PCA evidenced the differences between clearwater streams and the blackwater stream: blackwaters had low dissolved oxygen and $\mathrm{pH}$ concentration, lentic waters and small-sized bottom categories, whereas clearwaters had the opposite characteristics (Fig. 1). The lowest $\mathrm{pH}$ values were associated to the blackwaters of rio Preto (ranged from 3.2 to 4.3). In most clearwater streams, the concentration of dissolved oxygen decreased from upstream to downstream, while the water temperature increased (Table 1).

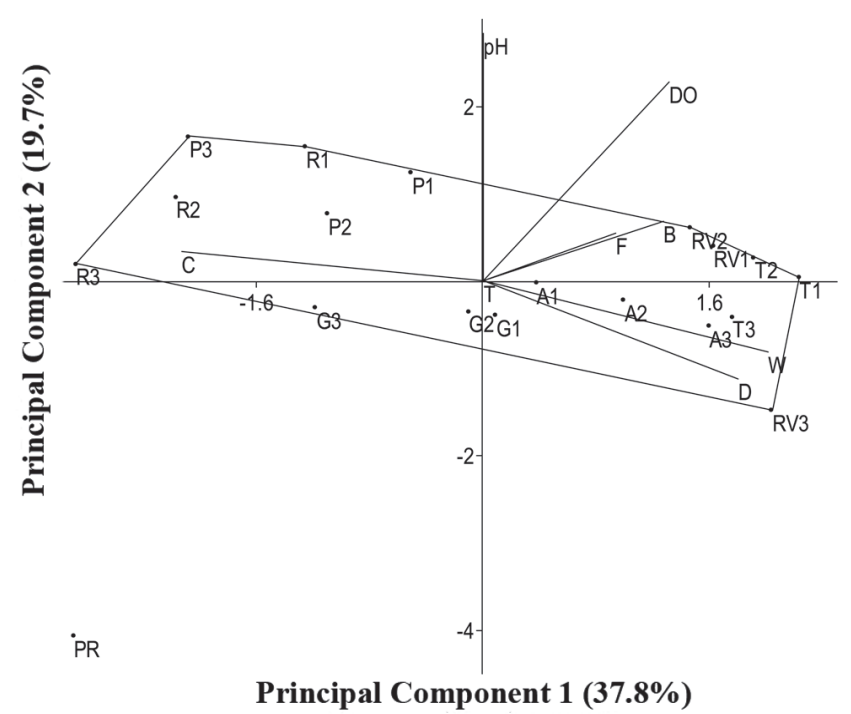

Fig. 1. Ordination resulted from principal components analysis, considering the structural habitat variables (width: W, depth: D, flow: F, and bottom: B), and the physical and chemical water variables $(\mathrm{pH}$, conductivity: $\mathrm{C}$, dissolved oxygen: DO, and temperature: T) in sites of Jureia-Itatins Ecological Station. Streams: Antas (A), Tetequera (T), Grajaúna $(\mathrm{G})$, "Ponte 2" (P), rio Verde (RV), "Riacho 1" (R), and rio Preto (PR). Stretches: upper (1), middle (2), and lower (3). Percentages of explanation of the axes are given in parentheses. Envelope designates clearwater streams.
The habitat diversity was higher in the headwaters (upper stretches), and decreased gradually toward downstream (middle and lower stretches) in clearwater streams, according to the Shannon index (Table 1).

\section{Ichthyofauna}

A total of 3,650 specimens of six orders, 11 families and 20 species of freshwater fish were captured (Table 2). The family Characidae predominated, mainly due to the abundance of Astyanax ribeirae, Mimagoniates microlepis, and Hollandichthys multifasciatus. Considering each of the 19 sampled sites, the observed species richness ranged from zero (upper reach of "Ponte 2") to 14 species (lower reach of ribeirão Grajaúna) (Table 2). Upper stream stretches had much lower species richness, whereas middle and lower sites were more species-rich but had similar values (Table 2, Fig. 2a). The same pattern was observed for ichthyofauna diversity among stream stretches: according to Shannon index, ichthyofauna was much less diverse in the upper reaches, whereas middle and lower stretches were more diverse (Table 2, Fig. 2b).

Differences in ichthyofauna diversity using the Shannon index values were found among sites $(1,2,3)(\mathrm{F}=3.368, \mathrm{df}=$ $2, \mathrm{p}=0.046)$, but not between seasons $(\mathrm{F}=0.768, \mathrm{df}=3, \mathrm{p}=$ $0.520)$. The significant interaction between sites and habitat diversity $(\mathrm{F}=3.587, \mathrm{df}=2, \mathrm{p}=0.038)$ indicated that the relationship between ichthyofauna diversity and habitat diversity among sites $(1,2,3)$ were not the same. In the upper sites (1), species diversity decreased as the habitat diversity increased ( $p=0.035)$, while in the lower sites (3) there was an opposite trend $(p=0.205)$. In the middle sites $(2)$ there was a trend similar to that found for the upper sites, but it was not significant $(\mathrm{p}=0.821)$.

Overall, the similarity was greater among stretches of the same stream according to ichthyofauna abundance, as showed by cluster analysis (Fig. 3). The similarity was also greater between streams of same drainages: middle and lower stretches of ribeirão Grajaúna were ordinate closer to rio Preto, stretches of "Riacho 1" were closer to rio Verde, and ribeirão Tetequera was nearer to ribeirão das Antas stretches. The upper stretches of studied streams had lower species similarity among them, which evidence the presence of a few species in common between these headwaters environments.

The CCA ordered the ichthyofauna according to their abundance in each site in relation to habitat characteristics (Fig. 4). In general, the CCA evidenced the differences in species composition among clear and blackwater streams: the low $\mathrm{pH}$ concentration of blackwaters explained the abundance of Mimagoniates microlepis, Characidium pterostictum, Pseudotothyris obtusa, Hyphessobrycon griemi, $\mathrm{H}$. reticulatus, and Scleromystax macropterus at rio Preto. The abundance of some of these species approached the rio Preto with middle and lower Grajaúna clearwater stretches. To "Riacho 1 " and "Ponte 2" streams, the high conductivity and $\mathrm{pH}$ concentration were determinant to abundance of Hollandichthys multifasciatus in these streams. The occurrence of Characidium cf. schubarti and Kronichthys 
Table 2. Total number of individuals (N), biomass (B), and average standard length (SL) of fish species from all sites, species richness, Shannon diversity index considering the ichthyofauna $\left(H^{\prime}{ }_{\text {ichthvofuna }}\right)$ of each sampled site in Jureia-Itatins Ecological Station, between April 2009 and February 2010. Streams: Antas (A), Tetequera (T), Grajaúna (G), "Ponte 2" (P), rio Verde (RV), "Riacho 1", and rio Preto (PR). Stretches: upper (1), middle (2), and lower (3). Site-specific columns represent the number of individuals for each species.

\begin{tabular}{|c|c|c|c|c|c|c|c|c|c|c|c|c|c|c|c|c|c|c|c|c|c|c|}
\hline Species (Acronym) & $\mathrm{N}$ & $\mathrm{B}(\mathrm{g})$ & $\mathrm{SL}(\mathrm{cm})$ & $\mathrm{A} 1$ & A2 & A3 & $\mathrm{T} 1$ & $\mathrm{~T} 2$ & $\mathrm{~T} 3$ & G1 & G2 & G3 I & $\mathrm{P} 1 \mathrm{I}$ & $\mathrm{P} 2$ & $\mathrm{P} 3$ & RV1 & RV2 & RV3 & $\mathrm{R} 1$ & $\mathrm{R} 2$ & R3 & PR \\
\hline Astyanax ribeirae (Arib) & 1032 & 21900.8 & 4.0 & & 106 & 103 & 205 & 569 & 32 & & 8 & 9 & & & & & & & & & & \\
\hline Mimagoniates microlepis (Mmic) & 853 & 384.1 & 3.0 & & 38 & 54 & & 2 & & & 198 & 231 & & & & & & & & & & 330 \\
\hline Phalloceros cf. reisi (Prei) & 660 & 206.4 & 2.5 & & 62 & 90 & & 131 & 22 & 1 & 53 & 16 & & 157 & 11 & & 45 & 13 & 13 & 18 & 27 & 1 \\
\hline Hollandichthys multifasciatus (Hmul) & 353 & 2025.9 & 6.1 & & 10 & & & 11 & 2 & 3 & 18 & 4 & & 86 & 46 & & & 1 & 66 & 61 & 29 & 16 \\
\hline Pseudotothyris obtusa (Pobt) & 112 & 32.9 & 2.4 & & & & & & & & 1 & 40 & & & & & & & & & & 71 \\
\hline Characidium cf. pterostictum (Cpte) & 100 & 63.9 & 3.3 & & & & & & & & 19 & 39 & & & & & & & & & & 42 \\
\hline Acentronichthys leptos (Alep) & 94 & 152.9 & 6.0 & & 10 & 9 & & 1 & 2 & 9 & 16 & 20 & & 11 & 10 & & & & & & & 6 \\
\hline Characidium lauroi (Clau) & 71 & 23.9 & 2.8 & 2 & 21 & 5 & 3 & 21 & & & 3 & 14 & & & & & 1 & & & & 1 & \\
\hline Rhamdia quelen (Rque) & 66 & 3377.6 & 14.7 & & 19 & 1 & & & & 4 & 7 & 2 & & 6 & 26 & & & & & & & 1 \\
\hline Schizolecis guntheri (Sgun) & 58 & 24.7 & 2.9 & & & & & 13 & 29 & & 9 & & & & & & 7 & & & & & \\
\hline Gymnotus pantherinus & 48 & 625.4 & 17.7 & & & & & & 6 & & 9 & 6 & & 8 & 5 & 2 & 5 & & & 2 & & 5 \\
\hline Hyphessobrycon griemi (Hgri) & 41 & 9.1 & 2.1 & & & & & & & & & 3 & & & & & & & & 2 & & 36 \\
\hline Antlantirivulus santensis (Rsan) & 39 & 29.8 & 3.7 & & & & & & & & & 1 & & 9 & & & & & 7 & 15 & 7 & \\
\hline Characidium cf. schubarti (Csch) & 35 & 65.6 & 4.5 & 8 & & & & & & & & & & & & 24 & 3 & & & & & \\
\hline Hyphessobrycon reticulatus (Hret) & 27 & 18.7 & 3.0 & & & & & & & & 1 & 2 & & & & & & & & & & 24 \\
\hline Kronichthys heylandi (Khey) & 24 & 16.8 & 3.3 & & & & & & & & & & & & & 1 & 22 & 1 & & & & \\
\hline Geophagus brasiliens & 21 & 307.9 & 6.5 & & 6 & 8 & & 5 & & & & 1 & & & & & & & & & & 1 \\
\hline Scleromystax macropterus (Smac) & 11 & 19.8 & 3.6 & & & & & & & & & & & & & & & & & & & 11 \\
\hline Hoplias malabaricus (Hmal) & 3 & 253.5 & 15.7 & & 1 & & & 1 & 1 & & & & & & & & & & & & & \\
\hline Synbranchus marmoratus (Smar) & 2 & 41.3 & 30.0 & & & 1 & & 1 & & & & & & & & & & & & & & \\
\hline Total & 3650 & 9581.0 & & 10 & 273 & 271 & 208 & 755 & 94 & 17 & 342 & 389 & 02 & 277 & 98 & 27 & 83 & 15 & 86 & 98 & 64 & 543 \\
\hline Species richness & & & & 2 & 9 & 8 & 2 & 10 & 7 & 4 & 12 & 14 & 0 & 6 & 5 & 3 & 6 & 3 & 3 & 5 & 4 & 12 \\
\hline$H_{\text {ichthyofauna }}^{\prime}$ & & & & 0.50 & 1.71 & 1.3 & 0.08 & 0.82 & 1.46 & 1.15 & 1.50 & 1.49 & -1 & 1.11 & 1.3 & 0.42 & 1.24 & 0.49 & 0.69 & 1.0 & 1.03 & 1.38 \\
\hline
\end{tabular}

heylandi in rio Verde showed the difference between this site in relation to other clearwater streams. Overall, clearwater streams had larger bottom categories, higher flow velocity, dissolved oxygen and $\mathrm{pH}$ concentration in comparison to the blackwater stream.

\section{Discussion}

\section{Differences between clearwater streams and the blackwater stream}

The physical and chemical water variables do not seem to have influenced the distribution of species in clearwater streams, but the difference between fish assemblages composition of clearwater streams and the blackwater stream may have been influenced mainly by $\mathrm{pH}$, as evidenced by PCA and reinforced by CCA. Although our study covered only one blackwaters' stream due to limitations in the field, it is known that blackwaters invariably exhibit different characteristics from clearwaters, i.e., blackwaters are very acidic ( $\mathrm{pH}$ between 3 and 4.5 ) as a result of high concentration of humic substances (Janzen, 1974). Low pH concentration has strong effects on fish communities (Jackson et al., 2001), and lowland streams at JIES have acidic waters $(\mathrm{pH} \sim 4.0)$ (Por, 1986), similar to that found in the rio Preto (3.2 - 4.3). This condition can be stressful for most fish species; however, species that inhabit blackwater environments naturally tolerate low $\mathrm{pH}$ (Dunson et al., 1977) due to longterm selection for such tolerance (Jackson et al., 2001).
The second highest species richness in JIES streams was recorded in the rio Preto: Mimagoniates microlepis, Pseudotothyris obtusa, Characidium cf. pterostictum, Hyphessobrycon griemi and H. reticulatus were abundant species in blackwaters. These species were also sampled in two clearwater sites, but near rio Preto (middle and lower stretches of ribeirão Grajaúna, with slightly acid clearwaters). According to Menezes \& Weitzman (2009), M. microlepis is much more common in blackwater streams than previously thought. In fact, this species was more abundant in the rio Preto and at adjacent sites (ribeirão Grajaúna), than in clearwater streams distant from blackwater streams. At Itanhaém River in the coastal plain in the State of São Paulo, close to the JIES, Leung \& Camargo (2005) found this species only in blackwater streams.

In coastal streams, $P$. obtusa, C. pterostictum, H. griemi and H. reticulatus occur in clearwaters (Aranha et al., 1998; Leung \& Camargo, 2005; Becker et al., 2008), but some of these species are also abundant inhabiting blackwater streams (Leung \& Camargo, 2005). In addition, Scleromystax macropterus occurred exclusively in the rio Preto, which supports the assertion of Oyakawa et al. (2006) that the species shows a preference for lentic and blackwater streams. The high similarity found between fish assemblages of rio Preto and ribeirão Grajaúna is related to the fact that the first stream is a tributary of the latter, which may promote the mixing of ichthyofauna and the sharing of species, such as 
P. obtusa, Characidium cf. pterostictum, H. griemi and $H$. reticulatus. Thereby, the highest species richness was recorded at these sites.

The remarkable difference in the $\mathrm{pH}$ concentration between blackwaters and clearwaters, as widespread in the literature (e.g. Janzen, 1974; Por, 1986) and also obtained during this study, makes our results reliable although samples were taken in only one blackwater stream. We consider that it is extremely important to know the fish fauna of these habitats for their conservation, since blackwater streams are inserted into the coastal plain, which is highly threatened by deforestation due to increased urbanization.

\section{Clearwater's fishes vs. habitat structures}

In clearwater streams, the headwater stretches had lower richness and species diversity, while the opposite occurred in the middle and lower sites. Overall, the observed pattern of occurrence and distribution of fish species varied according to habitat structure, due to the longitudinal gradient in clearwater streams. In JIES, the mountain streams are high-gradient as they are inserted in mountain regions that may reach $900 \mathrm{~m}$. As the topography influences the geomorphology of coastal streams, the stream's reaches exhibit particular features (Por, 1986). Considering that biological communities change in a predictable way according to the geomorphological changes of the stream channel (Vannote et al., 1980), the differences in fish assemblage composition among stretches of clearwater's streams (upper, middle and lower) are probably related to habitat characteristics (stream depth, flow and bottom type) within stream's reaches.
The ichthyofauna is deeply influenced by depth, stream flow and bottom type (Angermeier \& Schlosser, 1989), which should therefore influence the structure of the ichthyofauna due to species' addition and substitution processes along the longitudinal gradient of distribution (Sheldon, 1968). In JIES, the headwaters (high altitude) characteristically had high current, deep pools, and bottom dominated by boulders and bedrocks; included riffles and rapids, which selects species able to withstand the strong current, such as Characidium spp. and Kronichthys heylandi. The middle stretches (moderate elevation) had a wider diversity of bottom types, and pools and riffles mesohabitat alternated. Fish species occurring in these sites tend to segregate according to the mesohabitat availability, and the occurrence of many species with different characteristics in the middle stretches of the sampled streams was probably due to this. In general, the occurrence of characids and poecilids species is related to pools or marginal backwater areas, while the presence of crenuchids and loricarids species is related to riffles (Sabino \& Silva, 2004). Astyanax ribeirae, Mimagoniates microlepis, Hollandichthys multifasciatus (characids), Phalloceros cf. reisi (poeciliid), Characidium cf. pterostictum, C. cf. schubarti, C. lauroi (crenuchids), Schizolecis guntheri, and Kronichthys heylandi (loricarids) occurred in those habitats in JIES. Finally, the lower stretches (low altitude) had slow flow, backwater areas with sandy bottom, pools and runs. These characteristics may have favored the occurrence of Acentronichthys leptos, Gymnotus pantherinus, Geophagus brasiliensis, Hoplias malabaricus, and Synbranchus marmoratus at lower sites.
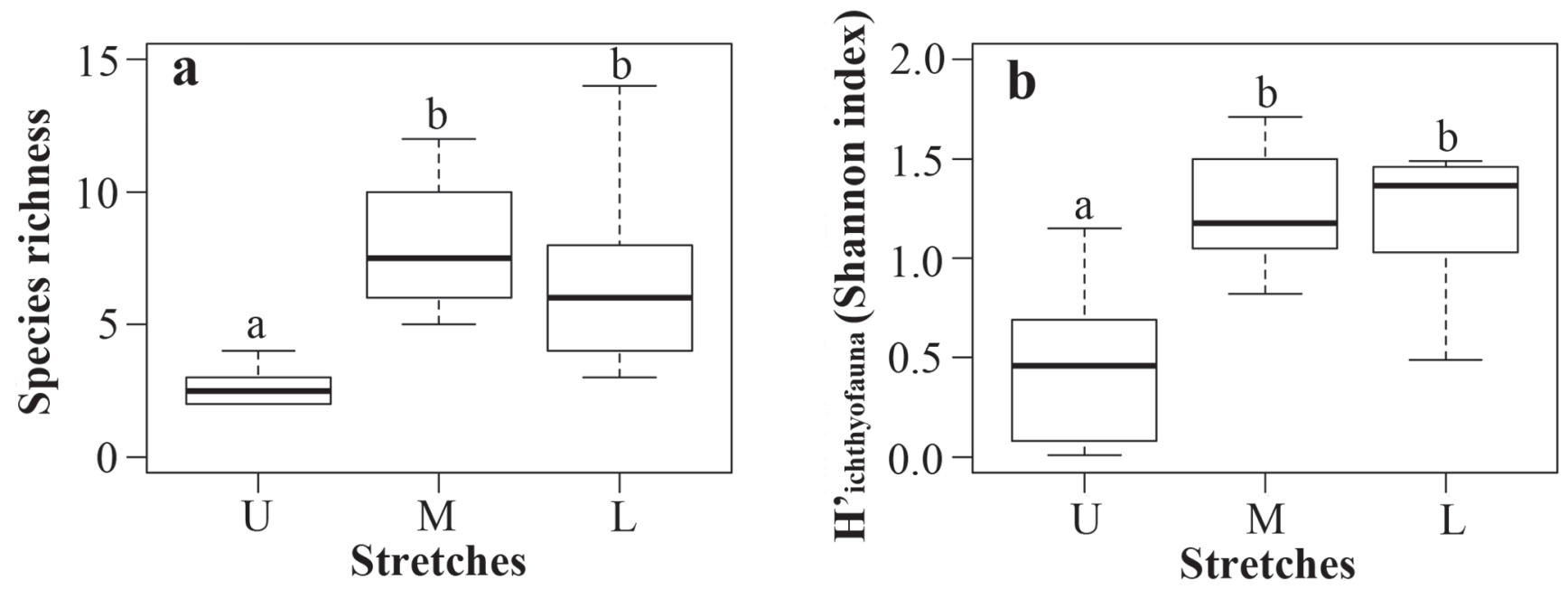

Fig. 2. Box-plots showing median (thick lines), first, and third quartiles (boxes), minimum and maximum values (whiskers) to upper (U), middle (M) and lower (L) stream stretches, according to ichthyofauna richness (A) and ichthyofauna diversity (B) in Jureia-Itatins Ecological Station. Different letters above each box-plot represents $p<0.05$ to post-hoc tests, and same letters represents $\mathrm{p}>0.05$. 


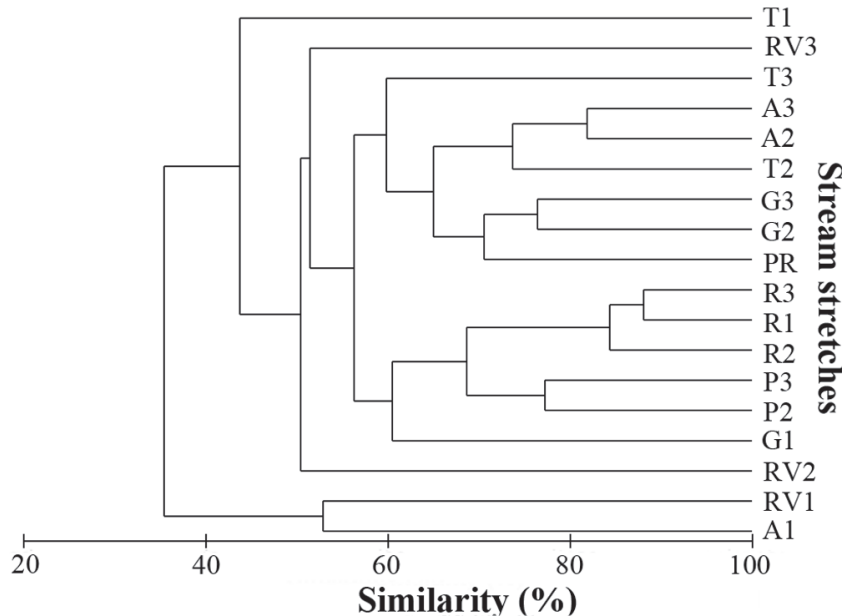

Fig. 3. Dendrogram of similarity produced by cluster analysis, according to ichthyofauna abundance data in each site of Jureia-Itatins Ecological Station. Streams: Antas (A), Tetequera (T), Grajaúna $(G)$, "Ponte 2" $(P)$, rio Verde $(R V)$, "Riacho 1" (R), and rio Preto (PR). Stretches: upper (1), middle (2), and lower (3).

\section{Seasonal distribution of species}

Temporal differences were not found in JIES's fish assemblages. In the study area, rainfall is high throughout the year without the presence of a pronounced dry season but a less rainy period (Marques \& Duleba, 2004), and thus possibly the species diversity is not seasonally different. According to Esteves \& Lobon-Cerviá (2001), torrential rains in coastal streams are common throughout the year and can influence fish's population size. These authors found that Mimagoniates, Schizolecis and Deuterodon were more abundant during the rainier season, and this may be related to the recruitment of young individuals in this period. The same possibly may have occurred in clearwater streams to Mimagoniates microlepis (also at rio Preto), and Hollandichthys multifasciatus which were more abundant in this study during the rainier season. However, some species such as Acentronichthys leptos, Characidium lauroi, C. pterostictum, Schizolecis guntheri, and Atlantirivulus santensis (clearwaters), and Pseudotothyris obtusa, Hyphessobrycon griemi, H. reticulatus, and Scleromystax macropterus (blackwaters), were more abundant during the drier season. In this case, the efficiency of electrofishing should be taken into consideration, since the sampling efficiency may be lower during the rainier season due to increased flow (and decreased conductivity), which consequently affects the electric field and facilitates the escape of fish (Zalewski \& Cowx, 1990).

\section{Concluding remarks}

In comparison to other Brazilian drainages, studies on coastal stream fish are scarce, which hinders the

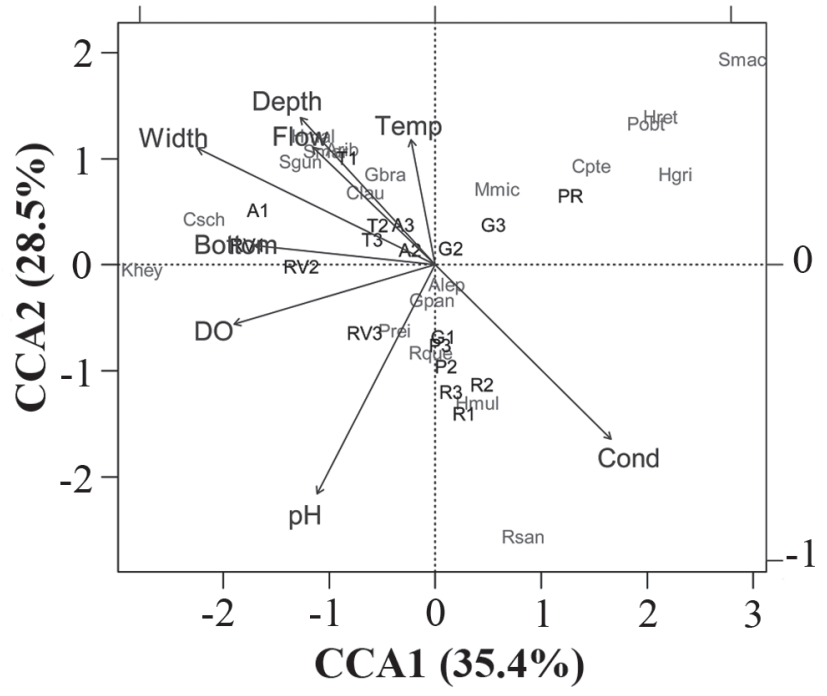

Fig. 4. Ordination resulted from canonical correspondence analysis according to ichthyofauna abundance in each site in relation to physical and structural characteristics of the habitat. Habitat variables: temperature (Temp), $\mathrm{pH}$ concentration $(\mathrm{pH})$, dissolved oxygen (DO), conductivity (Cond), stream width (Width), stream flow (Flow), bottom type (Bottom), and stream depth (Depth). Streams: Antas (A), Tetequera (T), Grajaúna $(\mathrm{G})$, "Ponte 2" (P), rio Verde (RV), "Riacho 1" (R), and rio Preto (PR). Stretches: upper (1), middle (2), and lower (3). Percentages of explanation of the axes are given in parentheses. The bottom and left-hand scales are for the sites and the fish species, the top and right-hand scales are for the habitat variables. The species acronyms are presented on Table 2.

understanding of several aspects of ichthyofauna composition and distribution. This study showed the importance of $\mathrm{pH}$ concentration for organization of fish assemblages when comparing clearwater streams and the blackwater stream. We also showed evidences for different relationships between habitat diversity and species diversity among stream stretches, indicating that habitat structure influences fish diversity in clearwater streams. However, we believe that the altitudinal gradient and even the isolation between streams can be also responsible for structuring the fish fauna in streams of clearwaters; therefore, these spatial issues should be focused on future studies. Finally, we concluded that temporal variation (seasonality) is not an important factor for structuring fish assemblages in coastal streams of the Atlantic forest.

Considering that the studied streams are located in a conservation area and exhibit pristine features, the results of this study should provide subsidies for species management in degraded areas. Furthermore, undisturbed environments have become increasingly scarce. Thus, our data may be used as references for other studies requiring 
such information. The presence of many endemic fish species (and some endangered) in JIES, reinforces the importance of legally protected areas from human impacts within the Atlantic forest biome.

\section{Acknowledgements}

This study was possible thanks to the dedication of the JIES' staff, especially Îlson Prado, Rubens Rogério de Prado, and Roberto Nicácio da Costa. CSG is also indebted to César Cestari for his dedication in the field and support, to Francisco Langeani who carefully identified fish species, and to Naércio Menezes that helped with Mimagoniates microlepis identification. We also thank IBAMA/ICMBio (15744) and COTEC (260108-000.197/0 2008) for licenses, Phyllis Reily for English revision, Lilian Casatti, Naércio A. Menezes, José Sabino, and Fábio C. Ferreira for comments, and three anonymous referees for suggestions that greatly improved the manuscript. This project was financially supported by CAPES and FAPESP(08/55029-5).

\section{Literature Cited}

Abilhoa, V., R. R. Braga, H. Bornatowski \& J. R. S. Vitule. 2011. Fishes of the Atlantic rain forest streams: ecological patterns and conservation. Pp. 259-282. In: Grillo, O. \& G. Venora (Eds.). Ecological Patterns and Conservation, Changing Diversity in Changing Environment, InTech. A

Angermeier, P. L. \& J. R. Karr. 1983. Fish communities along environmental gradients in a system of tropical streams. Environmental Biology of Fishes, 9: 117-135.

Angermeier, P. L. \& I. J. Schlosser. 1989. Species-area relationship for stream fishes. Ecology, 70: 1450-1462.

Aranha, J. M. R., D. F. Takeuti \& T. M. Yoshimura. 1998. Habitat use and food partitioning of the fishes in a coastal stream of Atlantic Forest, Brazil. Revista de Biología Tropical, 46: 951-959.

Barreto, A. P. \& J. M. R. Aranha. 2005. Assembléia de peixes de um riacho da Floresta Atlântica: composição e distribuição espacial (Guaraqueçaba, Paraná, Brasil). Acta Scientiarum. Biological Sciences, 27: 153-160.

Becker, F. G., S. Carvalho \& S. M. Hartz. 2008. Life-history of the South American darter, Characidium pterostictum (Crenuchidae): evidence for small scale spatial variation in a piedmont stream. Neotropical Ichthyology, 6: 591-598.

Bizerril, C. R. S. F. 1994. Análise taxonômica e biogeográfica da ictiofauna de água doce do leste brasileiro. Acta Biológica Leopoldensia, 16: 51-80.

Bizerril, C. R. S. F. 1995. Análise da distribuição espacial da ictiofauna de uma bacia hidrográfica do leste brasileiro. Arquivos de Biologia e Tecnologia, 38: 477-499.

Braga, F. M. S. \& P. M. Andrade. 2005. Distribuição de peixes na microbacia do Ribeirão Grande, Serra da Mantiqueira Oriental, São Paulo, Brasil. Iheringia, Série Zoologia, 95: 121-126.

Buck, S. \& I. Sazima. 1995. An assemblage of mailed catfishes (Loricariidae) in southeastern Brazil: distribution, activity and feeding. Ichthyological Exploration of Freshwaters, 6: 325-332.

Buckup, P. A. 1999. Sistemática e biogeografia de peixes de riachos. Pp. 91-138. In: Caramaschi, E. P., R. Mazzoni, C. R.
S. F. Bizerril \& P. R. E. Peres-Neto (Eds.). Ecologia de peixes de riachos. Rio de Janeiro, Computer \& Publish Editoração Ltda., 260p.

Buckup, P. A., N. A. Menezes \& M. S. Ghazzi. 2007. Catálogo das espécies de peixes de água doce do Brasil. Rio de Janeiro, Museu Nacional, 195p.

Casatti, L. 2005. Fish assemblage structure in a first order stream, southeastern Brazil: longitudinal distribution, seasonality, and microhabitat diversity. Biota Neotropica, 5: 1-9.

Clarke, K. R. \& R. N. Gorley. 2006. PRIMER v6: User manual/ tutorial. Plymouth Marine Laboratory, Plymouth, UK.

Deus, C. P. \& M. Petrere Jr. 2003. Seasonal diet shifts of seven fish species in an Atlantic rainforest stream in southeastern Brazil. Brazilian Journal of Biology, 63: 579-588.

Dunson, W. A., F. Swarts \& M. Silvestri. 1977. Exceptional tolerance to low $\mathrm{pH}$ of some tropical blackwater fish. Journal of Experimental Zoology, 201: 157-162.

Esteves, K. E. \& J. Lobón-Cerviá. 2001. Composition and trophic structure of a fish community of a clear water Atlantic rainforest stream in southeastern Brazil. Environmental Biology of Fishes, 62: 429-440.

Ferreira, C. P. \& L. Casatti. 2006. Influência da estrutura do hábitat sobre a ictiofauna de um riacho em uma micro-bacia de pastagem, São Paulo, Brasil. Revista Brasileira de Zoologia, 23: 642-651.

Ferreira, F. C. \& M. Petrere Jr. 2009. The fish zonation of the Itanhaém river basin in the Atlantic Forest of southeast Brazil. Hydrobiologia, 636: 11-34.

Gerhard, P., R. Moraes \& S. Molander. 2004. Stream fish communities and their associations to habitat variables in a rain forest reserve in southeastern Brazil. Environmental Biology of Fishes, 71: 321-340.

Gido, K. B. \& D. A. Jackson. 2010. Community ecology of stream fishes: concepts, approaches, and techniques. Bethesda, American Fisheries Society, Symposium 73, 684p.

Gilliam, J. F., D. F. Fraser \& M. Alkins-Koo. 1993. Structure of a tropical stream fish community - a role for biotic interactions. Ecology, 74: 1856-1870.

Gorman, O. T. \& J. R. Karr. 1978. Habitat structure and stream fish communities. Ecology, 59: 507-515.

Guimarães, A. T. B., M. S. Menezes \& A. C. Peret. 2010. Composição da ictiofauna em função da fisiografia de um riacho costeiro de Floresta Atlântica - Brasil. Biota Neotropica, 10: 57-65.

Hammer, Ø., D. A. Т. Harper \& P. D. Ryan. 2001. PAST: Paleontological statistics software package for education and data analysis. Palaeontologia Electronica 4: 9p.

Horwitz, R. J. 1978. Temporal variability patterns and the distributional patterns of stream fishes. Ecological Monographs, 48: 307-321.

Ibañez, C., J. Belliard, R. M. Hughes, P. Irz, A. Kamdem-Toham, L. Lamouroux, P. A. Tedesco \& T. Oberdorff. 2009. Convergence of temperate and tropical stream sh assemblages. Ecography, 32: 658-670.

Jackson, D. A., P. R. Peres-Neto \& J. D. Olden. 2001. What controls who is where in freshwater fish communities: the roles of biotic, abiotic, and spatial factors. Canadian Journal of Fisheries and Aquatic Sciences, 58: 157-170.

Janzen, D. H. 1974. Tropical blackwater rivers, animals, and mast fruiting by the Dipterocarpaceae. Biotropica, 6: 69-103.

Langeani, F., P. A. Buckup, L. R. Malabarba, L. H. R. Py-Daniel, C. A. S. Lucena, R. S. Rosa, J. A. S. Zuanon, Z. M. S. Lucena, M. R. Britto, O. T. Oyakawa \& G. Gomes-Filho. 2008. Peixes de água doce. Pp. 211-230. In: Rocha, R. M. \& W. A. Boeger 
(Eds.). Estado da arte e perspectivas para a Zoologia no Brasil. Curitiba, UFPR, 296p.

Legendre, P. \& L. Legendre. 1998. Numerical ecology. Amsterdam, Elsevier, 853p.

Leung, R. \& A. F. M. Camargo. 2005. Marine influence on fish assemblage in coastal streams of Itanhaém River basin, southeastern Brazil. Acta Limnologica Brasiliensia, 17: 219-232.

Lévêque, C., T. Oberdorff, D. Paugy, M. L. J. Stiassny \& P. A. Tedesco. 2008. Global diversity of fish (Pisces) in freshwater. Hydrobiologia, 595: 545-567.

Marques, O. A. V. \& W. Duleba. 2004. Estação Ecológica JuréiaItatins: ambiente físico, flora e fauna. Ribeirão Preto, Holos, 384p.

Matthews, W. J. 1998. Patterns in freshwater fish ecology. Massachusetts, Kluwer Academic Publishers, 756p.

Mattox, G. M. T. \& J. M. P. Iglesias. 2010. Ichthyofauna of Rio Jurubatuba, Santos, São Paulo: a high diversity refuge in impacted lands. Biota Neotropica, 10: 107-114.

Mazzoni, R. \& J. Lobón-Cerviá. 2000. Longitudinal structure, density and production rates of a neotropical stream fish assemblage: the river Ubatiba in the Serra do Mar, southeast Brazil. Ecography, 23: 588-602.

Mazzoni, R. \& R. Iglesias-Rios. 2002. Distribution pattern of two fish species in a coastal stream in southeast Brazil. Brazilian Journal of Biology, 62: 171-178.

Menezes, N.A. \& S. H. Weitzman. 2009. Systematics of the Neotropical fish subfamily Glandulocaudinae (Teleostei: Characiformes: Characidae). Neotropical Ichthyology, 7: 295-370.

Menezes, N. A., S. H. Weitzman, O. T. Oyakawa, F. C. T. Lima, R. M. C. Castro \& M. J. Weitzman. 2007. Peixes de água doce da Mata Atlântica: lista preliminar das espécies e comentários sobre conservação de peixes de água doce neotropicais. São Paulo, MZUSP, 407p.

Meyer, J. L. 1990. A blackwater perspective on riverine ecosystems. BioScience, 40: 643-651.

Moraes, A. J. 2001. Manual para avaliação da qualidade da água. São Carlos, Rima, 44p.

Myers, N., R. A. Mittermeier, C. G. Mittermeier, G. A. B. da Fonseca \& J. Kent. Biodiversity hotspots for conservation priorities. Nature, 403: 853-858.

Oyakawa, O. T. \& N. A. Menezes. 2011. Checklist dos peixes de água doce do Estado de São Paulo, Brasil. Biota Neotropica, 11: $1-13$.

Oyakawa, O. T., A. Akama, K. C. Mautari \& J. C. Nolasco. 2006. Peixes de riachos de Mata Atlântica nas Unidades de Conservação do Vale do rio Ribeira de Iguape no Estado de São Paulo. São Paulo, Neotrópica, 291p.

Oyakawa, O. T., N. A. Menezes, O. A. Shibatta, F. C. T. Lima, F. Langeani, C. S. Pavanelli, D. T. B. Nielsen \& A. W. S. Hilsdorf. 2009. Peixes de água doce. Pp. 349-424. In: Bressan, P. M., M. C. M. Kierrulff \&A. M. E. Sugieda (Eds.). Fauna ameaçada de extinção no Estado de São Paulo: Vertebrados. São Paulo, Fundação Parque Zoológico de São Paulo, Secretaria do Meio Ambiente, 645p.

Por, F. D. \& R. M. Lopes. 1994. The streams of the Atlantic rainforest of Brazil. Verhhandlungen Internationale Vereinigung für Theoretische und Angewandte Limnologie, 25: 1871-1875.

Por, F. D. 1986. Stream type diversity in the Atlantic lowland of the Juréia area (Subtropical Brazil). Hydrobiologia, 131: 39-45.
Por, F. D. 2004. Hidrobiologia da Juréia e da baixada do Ribeira rios e manguezais. Pp. 51-57. In: Marques, O. A. V. \& W. Duleba (Eds.). Estação Ecológica Juréia-Itatins: ambiente físico, flora e fauna. Ribeirão Preto, Holos, 384p.

R Development Core Team. 2012. R: A language and environment for statistical computing. R Foundation for Statistical Computing, Vienna, Austria. http://www.R-project.org.

Rezende, C. F., M. Moraes, L. R. Manna, R. P. Leitão, E. P. Caramaschi \& R. Mazzoni. 2010. Mesohabitat indicator species in a coastal stream of the Atlantic rainforest, Rio de JaneiroBrazil. Revista de Biología Tropical, 58: 1479-1487.

Ribeiro, A. C. 2006. Tectonic history and the biogeography of the freshwater fishes from the coastal drainages of eastern Brazil: an example of faunal evolution associated with a divergent continental margin. Neotropical Ichthyology, 4: 225-246.

Ribeiro, A. C., F. C. T. Lima, C. Riccomini \& N. A. Menezes. 2006. Fishes of the Atlantic rainforest of Boracéia: testimonies of the Quaternary fault reactivation within a Neoproterozoic tectonic province in southeastern Brazil. Ichthyological Exploration of Freshwaters, 17: 157-164.

Ribeiro, M. C., J. P. Metzger, A. C. Martensen, F. J. Ponzoni \& M. M. Hirota. 2009. The Brazilian Atlantic Forest: how much is left, and how is the remaining forest distributed? Implications for conservation. Biological Conservation, 142: 1141-1153.

Sabino, J. \& C. P. D. Silva. 2004. História natural de peixes da Estação Ecológica Juréia-Itatins. Pp: 230-242. In: Marques, O. A. V. \& W. Duleba (Eds.). Estação Ecológica Juréia-Itatins: ambiente físico, flora e fauna. Ribeirão Preto, Holos, 384p.

Sampaio, D., V. C. Souza, A. A. Oliveira, J. Paula-Souza \& R. R. Rodrigues. 2005. Árvores da restinga: guia de identificação. São Paulo, Neotrópica, 277p.

Serra, J. P., F. R. Carvalho \& F. Langeani. 2007. Ichthyofauna of the rio Itatinga in the Parque das Neblinas, Bertioga, São Paulo State: composition and biogeography. Biota Neotropica, 7: 81-86.

Sheldon, A. L. 1968. Species diversity and longitudinal succession in stream fishes. Ecology, 49: 193-198.

Uieda, V. S. \& W. Uieda. 2001. Species composition and spatial distribution of a stream fish assemblage in the east coast of Brazil: comparison of two field study methodologies. Revista Brasileira de Biologia, 61: 377-388.

Vannote, R. L., G. W. Minshall, K. W. Cummins, J. R. Sedell \& C. E. Cushing. 1980. The river continuum concept. Canadian Journal of Fisheries and Aquatic Sciences, 37: 130-137.

Winemiller, K. O., A. A. Agostinho \& E. P. Caramaschi. 2008. Fish ecology in tropical streams. Pp. 107-146. In: Dudgeon, D. (Ed.) Tropical stream ecology. London, Academic Press, 324p.

Zalewski, M. \& I. G. Cowx. 1990. Factors affecting the efficiency of electric fishing. Pp. 89-111. In: Cowx, I. G. \& P. L. Amarque (Eds.). Fish with electricity: applications in freshwater fisheries management. Oxford, Fishing New Books, 243p.

Submitted September 15, 2011

Accepted September 4, 2012

Published September 28, 2012 